\title{
A regionális tudomány és a Regionális Kutatások Intézete
}

\author{
Regional sciences and the Institute for Regional Studies \\ PÁLNÉ KOVÁCS ILONA
}

\begin{abstract}
PÁLNÉ KOVÁCS Ilona: kutatóprofesszor, Közgazdaság- és Regionális Tudományi Kutatóközpont, Regionális Kutatások Intézete; 7621 Pécs, Papnövelde u. 22.; egyetemi tanár, Pécsi Tudományegyetem, Bölcsészettudományi Kar; 7624 Pécs, Ifjúság útja 6.; palne@rkk.hu; https://orcid.org/0000-0003-2286-6326
\end{abstract}

KULCSSZAVAK: Regionális Kutatások Központja; regionális politika; tudománypolitika

\begin{abstract}
Ilona PÁLNÉ KOVÁCS: research professor, Institute for Regional Studies, Centre for Economic and Regional Studies; Papnövelde u. 22., H-7621 Pécs, Hungary; professor, Faculty of Humanities, University of Pécs; Ifjúság útja 6., H-7624 Pécs, Hungary; palne@rkk.hu; https://orcid.org/0000-0003-2286-6326
\end{abstract}

KEYWORDS: Institute for Regional Studies; regional policy; scientific policy

Minden tudományos közösségnek érdemes időnként rovancsot csinálnia, ezért üdvözölhető a vitacikk szerzőinek vállalkozása. Különösen indokolt az értékelés akkor, amikor sok tekintetben válságjelek mutatkoznak a hazai regionális tudományi intézmények müködésében. Egy tudományterület fejlődése természetesen nem írható le csupán az érintett intézmények sorsával, hanem tartalmi, módszertani értelemben is sok objektív és szubjektív, belső és külső tényezőtől függ. Olyan tudományterületen azonban, ahol az intézményesülés szakasza igazán még le sem zárult, még általunk is belátható és megélt időszakban zajlott, különösen beszédes maguknak az intézményeknek a sorsa, helyzete. Különösen igaz ez az MTA Regionális Kutatások Központjára, amelyik a hazai regionális tudományok bázisintézményének tekinthető, és mintegy harminc éves története visszatükrözi mind a regionális politikában, mind a tudománypolitikában és a kormányzásban bekövetkezett változásokat.

Vélhetően azért kaptam a felkérést, hogy az MTA Regionális Kutatások Központja (jelenlegi nevén KRTK Regionális Kutatások Intézete) szerepére reagáljak, mert már negyvenegy éve dolgozom Pécsett, a Papnövelde utcai épületben. A bejáratnál a névtáblák elég gyakran cserélődtek, szimbolizálva a viszonylag hosszú múltat. A jogelőd Dunántúli Tudományos Intézetet 1943-ban alapították, de utána is többször élt át intézményi reformokat. A DTI-t az ötvenes években tagolták be az akadémiai hálózatba, majd a hetvenes években kezdte meg a jelenlegi profilját megalapozó működését. Az igazi áttörést a nyolcvanas évek hozták. Nem hiszem, hogy lehet vitatkozni azzal az állítással, hogy az 1984-ben létrehozott RKK, 
és annak első főigazgatói (Enyedi György, Illés Iván, Horváth Gyula) oroszlánrészt vállaltak a regionális tudomány intézményi kereteinek hazai kiépülésében, egyben évtizedekig fazont és irányt is adtak a regionális kutatásoknak. Jórészt az általuk jegyzett időszak tekinthető az intézet virágkorának. Az intézet, illetve központ névválasztása jól tükrözi az alapításkori szándékot. Nem par excellence regionális „tudományi” mủhely jött létre, hanem regionális kutatásoknak helyet adó központ, egy tudatosan nyitott, interdiszciplináris, térben is leképezett hálózat, amelyik fö missziójának tartotta a tér megismerését és a térbeliség iránti, divatos kifejezéssel élve, közpolitikai érzékenyítést. Az RKK születésének és terjeszkedésének időszaka különösen kedvezett ennek a szerepnek. Már a nyolcvanas években megjelent a területi politika, a területi problémák iránti társadalmi érzékenység és a területi szempontok és érdekek iránti nagyobb tolerancia, persze az egypártrendszer és tervgazdaság adta korlátok között. A rendszerváltás, majd az Európai Unióhoz való csatlakozás motivációja stabilizálta azonban igazán a decentralizáció és regionalizmus iránti tudományos és politikai érdeklődést, sajnos, mint később kiderült, csak átmenetileg. A hálózat folyamatosan gyarapodó kutatógárdája olyan helyi és európai szak- és közpolitikai tudásra tett szert, ami akkortájt nagyon értékes volt mind a helyi döntéshozók, mind a csatlakozásra készülő központi kormányzat számára. Az intézet kutatói egyszerre dolgoztak helyi és nemzeti szintű fejlesztési terveken, koncepciókon. Megalapozták az EU-ban mintaértékünek tekintett területfejlesztési törvényt, olyan értékeket, elveket képviselve, amelyek áthatják a regionális tudományi gondolkodást nem csupán a közpolitikai tanulás, hanem a tudományos objektivitás szintjén is. Kétségtelen, hogy az alkalmazott kutatási profil mintegy másfél évtizedig erőteljesebben érvényesült, de egyáltalán nem az ehhez szükséges tudományos minőség kárára. A központ kutatói elsajátították a regionális tudományi kutatások elméleti és módszertani alapjait, bekapcsolódtak a nemzetközi kutatási hálózatokba. Különös érdemük, hogy kezdeményezték, segítették a regionális tudományi felsőoktatás bázisainak kiépülését is, eleinte a vezető kutatók, majd a középgeneráció személyesen is szerepet vállalt az oktatásban, mester- és doktori programok indításában. Elfogultság nélkül állítható, hogy a hazai területfejlesztési szakma kinevelése, mind a központi kormányzati, mind a területi intézmények szintjén a Regionális Kutatások Központja kutatóinak vezetésével zajlott.

Az RKK nemcsak ,jókor, jó helyre” érkezett, jelentőségét a mérete is megalapozta. A virágkorában több mint 100 kollégát foglalkoztató mủhely méretének köszönhetően nemcsak arra volt képes, hogy jelen legyen az ország minden régiójában, hanem arra is, hogy a legkülönbözőbb, egymással együttműködő tudományterületek (geográfia, közgazdaságtudomány, szociológia, jog- és politikatudomány) képviselőit bevonja a kutatásokba. A méret és az interdiszciplináris jelleg együttesen tette lehetővé, hogy az RKK tudományos és közpolitikai nagyvállalkozások végrehajtására is alkalmas volt. Amikor az országos könyvkiadók még nem mozdultak a regionális tudomány irányába, illetve amikor a tudomány- 
metriában még nem élvezett prioritást a nemzetközi referált folyóiratokban való megjelenés, az RKK saját forrásaiból jelentetett meg monográfiákat, sorozatokat, folyóiratot alapított, rangos hazai és nemzetközi konferenciákat szervezett. Az RKK-t az akadémia is ,jól menő" intézetnek tartotta, amelyik képes volt hazai és nemzetközi forrásokat bevonni olyan tudománypolitikainak tekinthető tevékenységekbe, amelyeket nem egy kutatóintézetnek, hanem a kormányzatnak vagy közvetlenül a tudománypolitikai intézményrendszernek kellett volna finanszíroznia. A tevékenység diverzifikáltsága anyagi előnyökkel járt, de hangsúlyozni szeretném, hogy nem személyes jövedelem formájában, hanem a közös vállalkozások, infrastruktúra kiépítésére fordítva.

Az RKK a 2012-es akadémiai intézeti reform során szenvedte el az első komoly csapást, amit máig nem hevert ki. Létszáma, telephelyeinek száma drasztikusan csökkent. A veszteségek azonban szorosan összefüggenek az általa művelt tudományos témakörök politikai és tudománypolitikai jelentőségének visszaszorulásával is. Az uniós csatlakozás után, majd különösen a 2010-es választásokat követő kormányzási ciklusokban a tágabb értelemben vett regionalizmus pozíciója megrendült, alig van igény területi elemzésekre vagy az uniós kohéziós politika közvetítésére. A területi egyenlőtlenségek iránti érzékenység, sőt az uniós tagság politikai presztízse is felszámolódott. A rendkívüli méreteket öltő kormányzati centralizáció felszámolta az alig „összetákolt” régiókat, kiszorította a hatalomból az önkormányzatokat, a városok, régiók versenyképességét nem a helyi erőforrásokra, hanem a központi, klientista elvű elosztásra alapozza.

Ilyen politikai és közpolitikai kontextusban nem sok helye van már a regionalistáknak a kormányzati területfejlesztési politika segítésében. Az intézet kutatói választásra kényszerültek. Természetesen a kedvezőtlen külső tényezők önmagukban nem magyarázzák meg, hogy miért individualizálódott az a kutatói közösség, amelyiknek az ereje korábban éppen a közös vállalkozásokban rejlett. Nyilvánvaló, hogy az új körülmények között az új generáció keresi a helyét, új kutatási témákat, profilokat, kutatási koreográfiákat testesít meg. Érzékelhetően csökken az alkalmazott kutatási dominancia, a regionalisták új generációja közelebb került a regionális tudomány alapkutatási, elméleti, illetve módszertani fövonalához. Az RKK versenyképességének nem ártott önmagában az sem, hogy megizmosodtak az egyetemi regionális tudományi műhelyek, színesítve a palettát, erősítve a színvonalat, a módszertani, elméleti felkészültséget. A többszereplős regionális tudományi intézményrendszer jelentős szinergiák forrása lehet. Nem pótolhatják azonban a kisebb egyetemi mühelyek az RKK szerepét, ami a méretéből, interdiszciplináris összetételéből és térben hálózatos jellegéből fakad.

Az újabb átszervezés lehetséges következményeivel kapcsolatban borúlátó vagyok, bár egyelőre inkább elvi, mintsem megtapasztalt evidenciák alapján. Különösen az teszi törékennyé az intézet helyzetét, hogy kikerült az MTA tudományos függetlenséget garantáló szervezeti kereteiből, kapacitásai, lehetőségei jórészt a kormányzati hozzáálláson múlnak, amelyik jelenleg nem rokonszenvez 
a „regionalizmussal”. Aggódom, hogy egy nagyszerü kezdeményezés, egy nagyon fontos, komplex tudásbázis enyészik el, ami nem pusztán tudományos veszteség lenne - már ha az ország és minden régiója, városa, vidéke versenyképességét, a területi polarizáció kordában tartását továbbra is stratégiai célnak tartjuk. 